\title{
The mechanochemical synthesis of quinazolin-4(3H)-ones by controlling the reactivity of IBX
}

\author{
Md Toufique Alam, Saikat Maiti and Prasenjit Mal*
}

\author{
Full Research Paper \\ Address: \\ School of Chemical Sciences, National Institute of Science Education \\ and Research (NISER), HBNI, Bhubaneswar, PO Bhimpur-Padanpur, \\ Via Jatni, District Khurda, Odisha 752050, India; Tel: +919439613856 \\ Email: \\ Prasenjit Mal* - pmal@niser.ac.in \\ * Corresponding author \\ Keywords: \\ ball-mill; contact explosive; IBX; mechanochemical synthesis; \\ quinazolin-4(3H)-one
}

\author{
Beilstein J. Org. Chem. 2018, 14, 2396-2403. \\ doi:10.3762/bjoc. 14.216 \\ Received: 11 June 2018 \\ Accepted: 24 August 2018 \\ Published: 12 September 2018 \\ This article is part of the Thematic Series "Hypervalent iodine chemistry in \\ organic synthesis". \\ Guest Editor: T. Wirth
}

(C) 2018 Alam et al.; licensee Beilstein-Institut.

License and terms: see end of document.

\begin{abstract}
Performing any synthesis using several arylamines and hypervalent iodine(V) reagents by direct mixing is unrealistic because of the high exothermic reaction or explosion. Herein we demonstrate, when anilines were substituted with an amide group at the orthoposition, successful chemical reactions could be performed due to intramolecular control. At maximum contact of the reacting substances, i.e., under solvent-free mechanochemical conditions, 2-aminobenzamides, aryl-, alkylaldehydes and the iodine(V) reagent $o$-iodoxybenzoic acid (IBX) led to substituted quinazolin-4(3H)-one derivatives in fair yields.
\end{abstract}

\section{Introduction}

An iodine and ammonia mixture is a well-known contact explosive due to formation of $\mathrm{NI}_{3}$ [1]. Similarly, hypervalent iodines as oxidizing compounds [2] react violently with amines under solvent-free conditions [3]. Aryliodonium imides or iminoiodanes can be prepared by the treatment of electron-deficient amines with iodine(III). However, these compounds explode at higher temperatures [4] and hence are stored under inert atmosphere and low temperature [5]. Polyvalent iodine derivatives are versatile reagents for $\mathrm{C}-\mathrm{N}$ bond constructions $[4,6]$. Mechanochemical conditions such as ball milling are considered to be one of the premium techniques in solvent-free synthesis [7]. Under these conditions, maximum concentration is expected to put those systems under high stress and therefore violent exothermic reactions or even explosions may take place between hypervalent iodine reagents and electron-rich amines. For this reason, synthetic methods based on hypervalent iodine reagents and primary amines under solvent-free conditions or constrained media are limited [8]. Recently, we have described a method for the successful reaction of primary amines and hypervalent iodine(III) reagents by controlling the reactivity using an acid salt, $\mathrm{NaHSO}_{4}$, as additive [9].

\section{Results and Discussion}

The last few decades have witnessed a significant growth in organic synthesis using hypervalent iodines [10-12]. Their easy availability, high stability, controlled oxidizing ability, and en- 
vironmentally benign nature make them highly suitable for the development of new synthetic transformations [13-17]. The chemistry of iodine $(\mathrm{V})$ reagents has been well documented in a number of reviews [18-20]. In continuation of our research focus on the development of synthetic methods using iodinebased reagents [21-26], we here report a method for the synthesis of quinazolin-4 $(3 H)$-ones [27,28] (Figure 1) from 2-aminobenzamide and aldehydes in the presence of $o$-iodoxybenzoic acid (IBX) [29]. However, when mixing benzaldehydes, aniline and IBX under ball-milling conditions an explosion was observed (Figure 1a; Caution! see experimental section) [30,31] and similar observations were made with Dess-Martin periodinane (DMP). On the other hand, benzamide was found to be unreactive with IBX and no reaction was observed under similar conditions (Figure 1b). Also no explosion was observed when 2-aminobenzamide was treated with IBX in absence of any aldehyde (Figure 1c). However, reacting 2-aminobenzamide with aldehydes in the presence of IBX under similar conditions was found to be successful affording the corresponding quinazolin-4(3H)-ones (Figure 1d).

In a recent report we have shown a successful dehydrogenative cross-coupling or CDC reaction using a combination of prima- ry amines and phenyleneiodine diacetate (PIDA) under solventfree ball-milling conditions, i.e., at the highest possible contact of the reactants [9]. During the reaction with the stronger oxidant PIDA, the basicity of the amine was regulated using an externally added acid salt, $\mathrm{NaHSO}_{4}$ (Figure 2a). In Figure 2b, a comparison in the reactivities of arylamines in the presence of non-iodine-based oxidant oxone [32] and IBX (iodine-based oxidant) is shown. Anilines readily reacted with oxone leading to the formation of the azo derivatives [32], while their treatment with IBX led to explosive decomposition. The reactions of 2-aminobenzamide with arylaldehydes in the presence of IBX afforded quinazolin-4(3H)-ones at maximum contact of the reactants, i.e., under ball-milling conditions (Figure 2c).

Towards optimization of the reaction conditions, 2-aminobenzamide (1) and 4-ethylbenzaldehyde (2a) were chosen as model substrates (Table 1). Initially, $70 \%$ of 2-(4-ethylphenyl)quinazolin-4(3H)-one (3a) were obtained, when 1, 2a and 1.1 equiv of IBX were milled together for $1.5 \mathrm{~h}$ in a $10 \mathrm{~mL}$ ball-milling jar (Table 1, entry 1). However, the yield increased to $91 \%$ when IBX was added after 30 min of milling of the reactants $\mathbf{1}$ and $\mathbf{2 a}$ (Table 1, entry 2). Conversely, changing the amount of IBX to other than 1.1 equiv, a decrease in the prod- a)<smiles>Nc1ccccc1</smiles>

b)<smiles>NC(=O)c1ccccc1</smiles>

c)<smiles>NC(=O)c1ccccc1N</smiles>

d)<smiles>NC(=O)c1ccccc1N</smiles>

2-aminobenzamide
$+$<smiles>O=C1OI(=O)(O)c2ccccc21</smiles>

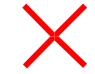

explosion mixing<smiles>O=C1OI(=O)(O)c2ccccc21</smiles>

no reaction<smiles>O=C1OI(=O)(O)c2ccccc21</smiles><smiles>CC</smiles>

no explosion

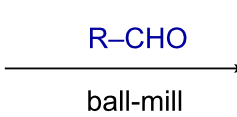

at maximum contact<smiles>[R]c1nc2ccccc2c(=O)[nH]1</smiles>

successful

$$
\mathrm{R}=\text { aryl or alkyl }
$$




\section{known}

a) aliphatic amine reactivity

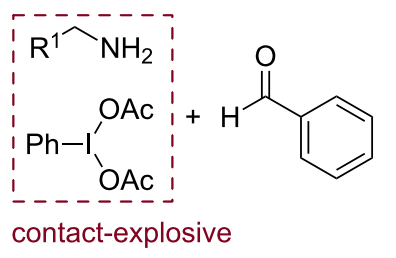

reaction controller<smiles>[R]CNC(=O)c1ccccc1</smiles>

contact-explosive

b) aromatic amine reactivity under ball milling
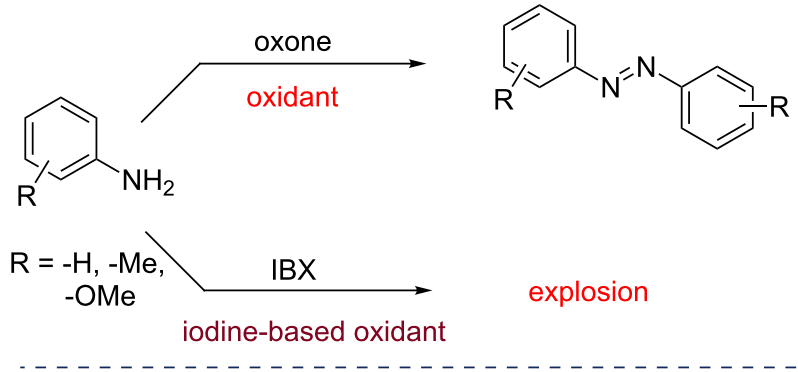

explosion

\section{this work}

c) quinazolin-4(3H)-one synthesis

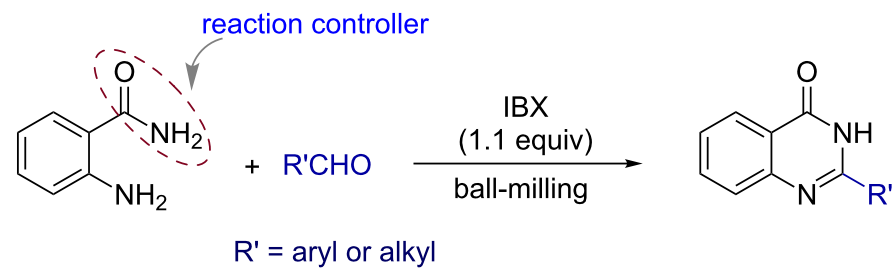

Figure 2: Comparison of the current work with the existing literature reports.

Table 1: Optimization of the reaction conditions. ${ }^{a}$<smiles>NC(=O)c1ccccc1N</smiles>

1<smiles>CCc1ccc(C=O)cc1</smiles>

$2 \mathbf{a}$

\section{reagent \\ silica gel, ball-mill,}

$1.5 \mathrm{~h}$<smiles>CCc1ccc(-c2nc3ccccc3c(=O)[nH]2)cc1</smiles>

$3 a$

\begin{tabular}{|c|c|c|}
\hline Entry & Reagent (equiv) ${ }^{b}$ & Yield $(\%)^{c}$ \\
\hline $1^{d}$ & $\mathrm{IBX}(1.1)$ & 70 \\
\hline 2 & $\operatorname{IBX}(1.1)$ & 91 \\
\hline 3 & $\mathrm{IBX}(1)$ & 78 \\
\hline 4 & $\mathrm{IBX}(1.2)$ & 85 \\
\hline $5^{e}$ & IBA (1.1)-oxone (1.5) & 59 \\
\hline $6^{f}$ & IBX (1.1) & 90 \\
\hline
\end{tabular}

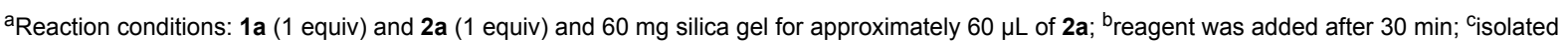
yields. ${ }^{d} \mathbf{1}, \mathbf{2 a}$ and IBX were added together; ${ }^{\mathrm{e}}$ 2-iodobenzoic acid (IBA). ${ }^{\mathrm{f}} \mathrm{IBX}$ added after $1 \mathrm{~h}$. 
uct yield was observed (Table 1, entries 3 and 4). The reaction also took place, albeit affording the product in lower yield, with in situ-generated IBX [33], i.e., by using an IBA (2-iodobenzoic acid)-oxone combination (Table 1, entry 5). Interestingly, when silica gel [34] was used as additive during the handling of liquid aldehydes, the yields of the products were found to be constant and reproducible. Interestingly no violent decomposition was observed, when IBX was added at the beginning of the reaction (Table 1 , entry 1 ), after $30 \mathrm{~min}$ (Table 1 , entry 2 ) or $1 \mathrm{~h}$ (Table 1, entry 6) of milling $\mathbf{1}$ and $\mathbf{2}$. Thus we conclude that the current method is explosion free.

After optimization of the reaction conditions, the scope of the synthesis of quinazolin-4(3H)-one derivatives was explored (Figure 3 and Figure 4) and the desired products were isolated in fair yields. The yields of quinazolin-4(3H)-one derivatives<smiles>C=CC(=C)CC</smiles>

3a, $91 \%, 1.5 \mathrm{~h}$<smiles>Cc1ccc(-c2nc3ccccc3c(=O)[nH]2)cc1</smiles>

$3 e, 82 \%, 1.5 \mathrm{~h}$<smiles>O=c1[nH]c(-c2ccccc2F)nc2ccccc12</smiles>

$3 i, 68 \%, 3.5 \mathrm{~h}$<smiles>O=c1[nH]c(-c2ccccc2-c2ccccc2)nc2ccccc12</smiles>

$3 \mathrm{~m}, 70 \%, 1.5 \mathrm{~h}$<smiles>CCc1ccccc1-c1nc2ccccc2c(=O)[nH]1</smiles>

3b, $95 \%, 1.5 \mathrm{~h}$<smiles>CC(C)c1ccc(-c2nc3ccccc3c(=O)[nH]2)cc1</smiles>

3f, $84 \%, 2 \mathrm{~h}$<smiles>COc1ccc(-c2nc3ccccc3c(=O)[nH]2)cc1</smiles>

3j, $89 \%, 3.5 \mathrm{~h}$<smiles>O=c1[nH]c(C2CCCCC2)nc2ccccc12</smiles>

3n, $65 \%, 3.5 \mathrm{~h}$<smiles>O=c1[nH]c(-c2ccccc2)nc2ccccc12</smiles>

3c, $79 \%, 1.5 \mathrm{~h}$<smiles>Cc1cc(C)c(-c2nc3ccccc3c(=O)[nH]2)c(C)c1</smiles>

$3 g, 35 \%\left(50 \%^{a}\right), 3 \mathrm{~h}$<smiles>O=c1[nH]c(-c2ccncc2)nc2ccccc12</smiles>

3k, $71 \%, 3 \mathrm{~h}$<smiles>CC(Cc1nc2ccccc2c(=O)[nH]1)c1ccccc1</smiles>

3o, $84 \%, 2 \mathrm{~h}$<smiles>Cc1ccccc1-c1nc2ccccc2c(=O)[nH]1</smiles>

3d, $92 \%, 2 \mathrm{~h}$<smiles>O=c1[nH]c(-c2ccccc2Br)nc2ccccc12</smiles>

3h, $94 \%, 4$ h<smiles>O=c1[nH]c(-c2cccc3ccccc23)nc2ccccc12</smiles>

3I, $52 \%, 4.5 \mathrm{~h}$<smiles>CCCc1nc2ccccc2c(=O)[nH]1</smiles>

$3 p, 68 \%, 2.5$ h 
<smiles>NC(=O)c1ccccc1N</smiles>

$3 q, 60 \%, 3 h$<smiles>COc1ccc(-c2nc3ccccc3c(=O)[nH]2)cc1Br</smiles>

3t, $76 \%, 1.5 \mathrm{~h}$<smiles>N#Cc1ccc(-c2nc3ccccc3c(=O)[nH]2)cc1</smiles>

$3 w, 60 \%, 3 \mathrm{~h}$<smiles>[R]C=O</smiles>

$3 r, 78 \%, 1 \mathrm{~h}$<smiles>Cc1cc(I)c(-c2nc3ccccc3c(=O)[nH]2)cc1C</smiles>

3u, $40 \%\left(78 \%^{a}\right), 4 \mathrm{~h}$<smiles>O=c1[nH]c(-c2ccc3ccc4cccc5ccc2c3c45)nc2ccccc12</smiles>

$3 x, 65 \%, 1.5 \mathrm{~h}$<smiles>[R]c1nc2ccccc2c(=O)[nH]1</smiles>

3<smiles>O=c1[nH]c(-c2cc(F)ccc2Br)nc2ccccc12</smiles>

3s, $50 \%, 1.5 \mathrm{~h}$<smiles>O=c1[nH]c(-c2ccc(F)cc2)nc2ccccc12</smiles>

$3 v, 59 \%, 1.5 \mathrm{~h}$

3y, $27 \%\left(64 \%^{\mathrm{a}}\right), 1.5 \mathrm{~h}$

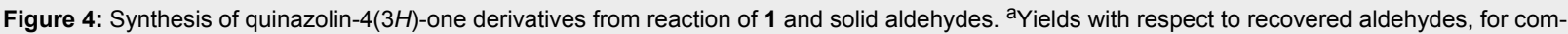
pound $3 y$, IBX was added after $1 \mathrm{~h}$.

were higher when monoalkyl-substituted benzaldehydes (3a,b and $3 \mathbf{d}-\mathbf{f}$ ) were used compared to the reaction with unsubstituted benzaldehyde $(\mathbf{3 c})$. However, sterically congested aromatic aldehydes afforded the desired quinazolin-4(3H)-ones $\mathbf{3 g}$ and $3 \mathbf{u}$ in relatively poor yields. The reactions were found to proceed smoothly and moderately yielding with halogenated aldehydes (3h, 3i, 3q-s, 3v) and the $p$-cyano-substituted aldehyde (3w). Methoxy-substituted aldehydes were giving quinazolin-4(3H)-ones in high yields $(\mathbf{3 j}, \mathbf{3 t})$. Likewise, the reaction was found to be successful with aldehydes containing fused aromatic ring systems like naphthyl (3I), pyrenyl (3x), anthryl (3y), etc. Several aliphatic aldehydes like cyclohexyl (3n), 3-phenylbutraldehyde (3o) and butyraldehyde (3p) furnished the corresponding heterocycles with higher efficiency. The synthesized products were characterized by standard analytical methods and the structure of 3a was confirmed by X-ray crystallographic analysis (Figure 5).

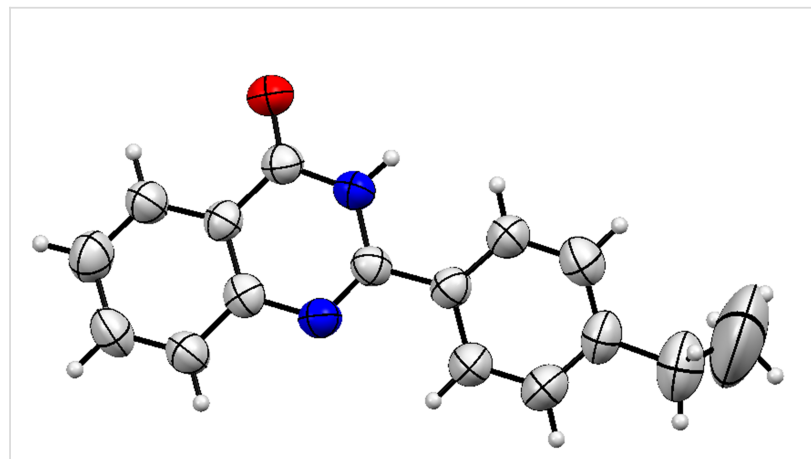

Figure 5: Crystal structure of 3a (CCDC No. 1823611).

Based on the results collected in Table 1 and literature precedence $[35,36]$, a mechanism of the quinazolin-4(3H)-ones synthesis is proposed and depicted in Figure 6. As it has been ob- 


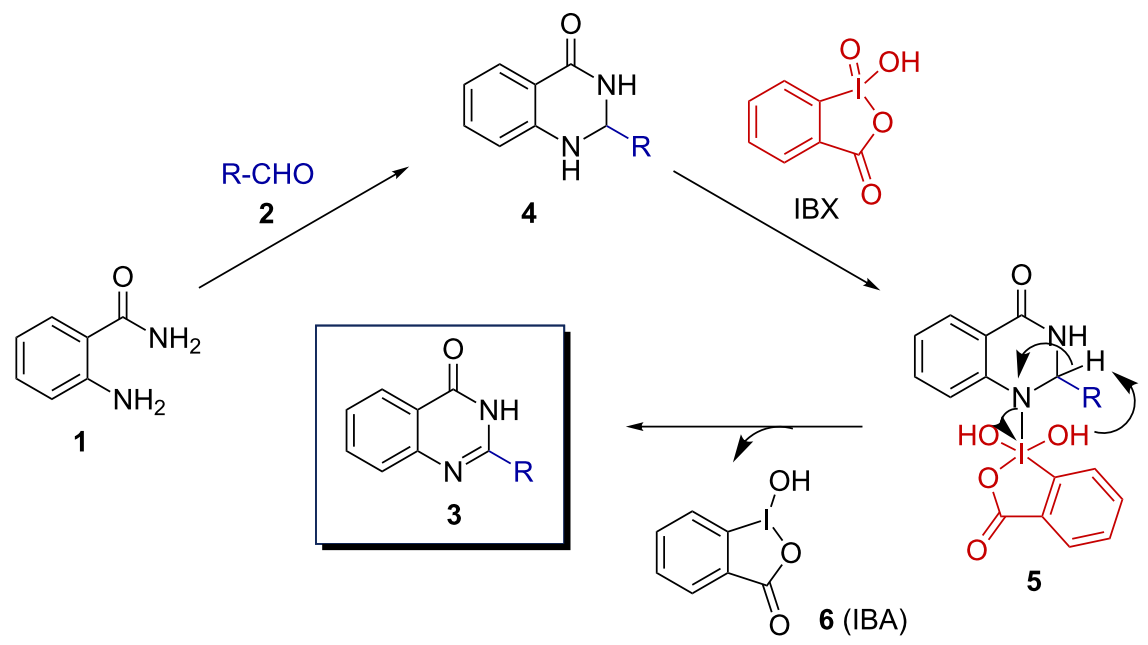

Figure 6: Plausible mechanism for the quinazolin-4(3H)-ones synthesis using IBX.

served that the yield of the reaction significantly increased when IBX was added after 30 min of initial milling of the reactants $\mathbf{1}$ and $\mathbf{2}$ it is anticipated that 2-aminobenzamide and the arylaldehyde formed the adduct $\mathbf{4}$. This intermediate then further reacted with IBX to generate $\mathbf{5}$. Finally, $\mathbf{5}$ led to the quinazolin-4(3H)-one 3 with the generation of IBA (6).

Arylamines caused explosion and benzamide was found to be unreactive with IBX. However, the reaction was found to be successful with 2-aminobenzamide under similar conditions (Figure 1). 2-Aminobenzamide having one highly reactive amine part and another unreactive part, can be considered an aniline derivative with moderate reactivity. Therefore, we anticipate that the controlled reactivity of IBX under mechanomilling conditions led to successful reaction with 2-aminobenzamide.

Finally, a large scale synthesis was performed to prove the synthetic utility of this methodology. By taking anthranilamide (1, $0.550 \mathrm{~g})$ and 4-ethylbenzaldehyde $(\mathbf{2 a}, 0.541 \mathrm{~mL})$, the reaction was carried out under optimized conditions. The 2-(4-ethyl-
phenyl)quinazolin-4(3H)-one (3a) was isolated in $68 \%$ yield (Scheme 1).

\section{Conclusion}

In conclusion, we have successfully demonstrated the synthesis of quinazolin-4(3H)-ones by the controlled use of IBX in the presence of 2-aminobenzamides. We foresee that controlled reactions of IBX in the presence of amines have certain advantages, e.g., many difficult reactions can be performed easily by choosing the appropriate reaction environment. The described methodology also highlights the advancement of quinazolin$4(3 H)$-ones synthesis chemistry and may find application in the context of mechanochemical reactions towards natural product synthesis and pharmaceutical chemistry.

\section{Experimental}

General methods. Ball-milling experiments were carried out open to atmosphere and at room temperature in a Retsch MM 200 high speed vibration mixture milling instrument $(21 \mathrm{~Hz})$. All yields mentioned are isolated yields after column chromatographic purifications of the compounds using silica gel<smiles>NC(=O)c1ccccc1N</smiles>

1

$(4.04 \mathrm{mmol})$ $0.550 \mathrm{~g}$
$\mathrm{OHC}$<smiles>c1ccc(C23CCCCC2C3)cc1</smiles>

2a

$(4.04 \mathrm{mmol})$ $0.541 \mathrm{~mL}$

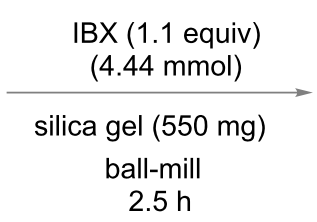<smiles>CCc1ccc(-c2nc3ccccc3c(=O)[nH]2)cc1</smiles>

$0.684 \mathrm{~g}, 68 \%$ 
(230-400 mesh) and hexane/ethyl acetate mixtures as eluent, unless otherwise specified. NMR spectra were recorded on either a $400 \mathrm{MHz}$ or a $700 \mathrm{MHz}$ instrument at $25^{\circ} \mathrm{C}$. The chemical shift values are reported in ppm (parts per million) with respect to residual chloroform $\left(7.26 \mathrm{ppm}\right.$ for ${ }^{1} \mathrm{H}$ and 77.16 for ${ }^{13} \mathrm{C}$ ) or DMSO $\left(2.5 \mathrm{ppm}\right.$ for ${ }^{1} \mathrm{H}$ and 39.5 for $\left.{ }^{13} \mathrm{C}\right)$. Data are reported as follows: chemical shift in ppm $(\delta)$, multiplicity ( $\mathrm{s}=$ singlet, $\mathrm{d}=$ doublet, $\mathrm{t}=$ triplet, $\mathrm{q}=$ quartet, $\mathrm{brs}=$ broad singlet, $\mathrm{m}=$ multiplet), coupling constant $(\mathrm{Hz})$ and integration. High-resolution mass spectra (HRMS) were recorded on an ESI-TOF (time of flight) mass spectrometer. IR (infrared) spectral data are reported in wave numbers $\left(\mathrm{cm}^{-1}\right)$. Melting points (mp) of the compounds were determined using a digital melting point apparatus and are uncorrected.

Caution. When aniline and IBX are mixed under solvent-free conditions or at maximum contact, immediate explosion was observed. However, no explosion could be observed under similar conditions when 2-aminobenzamide and arylaldehydes were reacted in the presence of IBX. However, it is highly recommended to consult the general safety protocols at the laboratory and all reactions should be carried out in a fume hood behind a blast shield.

2-Iodoxybenzoic acid (IBX) was prepared by following reported literature procedure [37].

General procedure for preparation of quinazolin-4(3H)ones. 2-Aminobenzamide (1, $0.44 \mathrm{mmol}, 1.0$ equiv), aldehyde (2, $0.44 \mathrm{mmol}, 1.0$ equiv), $60 \mathrm{mg}$ silica gel (only for liquid aldehydes) and a stainless-steel milling ball were added into a $10 \mathrm{~mL}$ stainless-steel jar. Milling was carried out for $30 \mathrm{~min}$ and then IBX ( $0.484 \mathrm{mmol}, 1.1$ equiv) was added to the mixture and milling was continued for $1 \mathrm{~h}$. The progress of the reaction was monitored by TLC after taking a small portion of the reaction mixture and dissolving it in DCM (with the appropriate solvent as eluent). After completion of the reaction, dichloromethane was used for extracting the compound from the solid reaction mixture. The solvent was evaporated to dryness and the crude reaction mixture was purified by silica gel column chromatography using an appropriate hexane/ethyl acetate mixture.

Large scale preparation of 3a: One third of the $25 \mathrm{~mL}$ stainless steel milling jar was filled with 2 -aminobenzamide (550 mg, $4.04 \mathrm{mmol}$ ), 4-ethylbenzaldehyde $(541.5 \mu \mathrm{L}$, $4.04 \mathrm{mmol}), 550 \mathrm{mg}$ silica gel and one ball (15 mm diameter). After $1 \mathrm{~h}$ of milling, IBX (1.24 g, $4.44 \mathrm{mmol})$ was added and milling continued for $1.5 \mathrm{~h}$. Then, after extraction of the reaction mixture with DCM, followed by silica gel column chromatography with ethyl acetate/hexane 1:5 as eluent provided product 3a (684 mg, 68\%).

\section{Supporting Information}

\section{Supporting Information File 1}

Characterization data, NMR spectra and crystallographic information.

[https://www.beilstein-journals.org/bjoc/content/ supplementary/1860-5397-14-216-S1.pdf]

\section{Acknowledgements}

The activity was supported by DST (New Delhi, India). We are thankful to Dr. Milan Kr. Barman (NISER, Bhubaneswar) for X-ray crystallographic analysis. MTA and SM are thankful to UGC (India) and CSIR (India) for fellowship, respectively.

\section{ORCID ${ }^{\circledR}$ iDs}

Prasenjit Mal - https://orcid.org/0000-0002-7830-9812

\section{References}

1. Tornieporth-Oetting, I.; Klapötke, T. Angew. Chem., Int. Ed. Engl. 1990, 29, 677-679. doi:10.1002/anie.199006771

2. Nicolaou, K. C.; Baran, P. S.; Kranich, R.; Zhong, Y.-L.; Sugita, K.; Zou, N. Angew. Chem., Int. Ed. 2001, 40, 202-206. doi:10.1002/1521-3773(20010105)40:1<202::aid-anie202>3.0.co;2-3

3. Hassel, O. Science 1970, 170, 497-502. doi:10.1126/science.170.3957.497

4. Dauban, P.; Dodd, R. H. Synlett 2003, 1571-1586. doi:10.1055/s-2003-41010

5. Zhdankin, V. V. Preparation, Structure and Properties of Polyvalent lodine Compounds. Hypervalent lodine Chemistry; John Wiley \& Sons Ltd: Chichester, UK, 2013; pp 21-143.

6. Zhdankin, V. V.; Stang, P. J. Chem. Rev. 2008, 108, 5299-5358. doi:10.1021/cr800332c

7. Achar, T. K.; Bose, A.; Mal, P. Beilstein J. Org. Chem. 2017, 13, 1907-1931. doi:10.3762/bjoc.13.186

8. Prasad, V.; Kale, R. R.; Mishra, B. B.; Kumar, D.; Tiwari, V. K. Org. Lett. 2012, 14, 2936-2939. doi:10.1021/ol3012315

9. Achar, T. K.; Mal, P. Adv. Synth. Catal. 2015, 357, 3977-3985 doi:10.1002/adsc.201500914

10. Yoshimura, A.; Zhdankin, V. V. Chem. Rev. 2016, 116, 3328-3435. doi:10.1021/acs.chemrev.5b00547

11. Muñiz, K. Top. Curr. Chem. 2015, 373, 105-133. doi:10.1007/128_2015_663

12. Dohi, T.; Kita, Y. Top. Curr. Chem. 2016, 373, 1-23. doi:10.1007/128_2016_667

13. French, A. N.; Bissmire, S.; Wirth, T. Chem. Soc. Rev. 2004, 33 , 354-362. doi:10.1039/B310389G

14. Pellissier, H. Beilstein J. Org. Chem. 2018, 14, 325-344. doi:10.3762/bjoc.14.21

15. Sharma, P.; Kaur, N.; Pareek, A.; Kishore, D. Sci. Rev. Chem. Commun. 2013, 3, 16-42.

16. Duschek, A.; Kirsch, S. F. Chem. - Eur. J. 2009, 15, 10713-10717. doi:10.1002/chem.200901867

17. Richardson, R. D.; Zayed, J. M.; Altermann, S.; Smith, D.; Wirth, T. Angew. Chem., Int. Ed. 2007, 46, 6529-6532. doi:10.1002/anie.200702313 
18. Singh, F. V.; Wirth, T. Synthesis 2013, 45, 2499-2511. doi:10.1055/s-0033-1339679

19. Yusubov, M. S.; Zhdankin, V. V. Curr. Org. Synth. 2012, 9, 247-272. doi:10.2174/157017912799829021

20. Ladziata, U.; Zhdankin, V. V. ARKIVOC 2006, No. ix, 26-58. doi:10.3998/ark.5550190.0007.903

21. Maiti, S.; Mal, P. J. Org. Chem. 2018, 83, 1340-1347. doi:10.1021/acs.joc.7b02841

22. Maiti, S.; Bose, A.; Mal, P. J. Org. Chem. 2018, 83, 8127-8138. doi:10.1021/acs.joc.8b00921

23. Maiti, S.; Alam, M. T.; Mal, P. Asian J. Org. Chem. 2018, 7, 715-719. doi:10.1002/ajoc.201800069

24. Maiti, S.; Mal, P. Org. Lett. 2017, 19, 2454-2457. doi:10.1021/acs.orglett.7b01117

25. Maiti, S.; Achar, T. K.; Mal, P. Org. Lett. 2017, 19, 2006-2009. doi:10.1021/acs.orglett.7b00562

26. Maiti, S.; Mal, P. Adv. Synth. Catal. 2015, 357, 1416-1424. doi:10.1002/adsc.201401110

27. Lee, J. B.; Kang, M. E.; Kim, J.; Lee, C. Y.; Kee, J.-M.; Myung, K.; Park, J.-U.; Hong, S. Y. Chem. Commun. 2017, 53, 10394-10397. doi:10.1039/C7CC05794F

28. Parua, S.; Das, S.; Sikari, R.; Sinha, S.; Paul, N. D. J. Org. Chem. 2017, 82, 7165-7175. doi:10.1021/acs.joc.7b00643

29. Achar, T. K.; Maiti, S.; Mal, P. RSC Adv. 2014, 4, 12834-12839. doi:10.1039/C4RA00415A

30. Hernández, J. G.; Bolm, C. J. Org. Chem. 2017, 82, 4007-4019. doi:10.1021/acs.joc.6b02887

31. James, S. L.; Adams, C. J.; Bolm, C.; Braga, D.; Collier, P.; Friščić, T.; Grepioni, F.; Harris, K. D. M.; Hyett, G.; Jones, W.; Krebs, A.; Mack, J.; Maini, L.; Orpen, A. G.; Parkin, I. P.; Shearouse, W. C.; Steed, J. W.; Waddell, D. C. Chem. Soc. Rev. 2012, 41, 413-447. doi:10.1039/C1CS15171A

32. Thorwirth, R.; Bernhardt, F.; Stolle, A.; Ondruschka, B.; Asghari, J. Chem. - Eur. J. 2010, 16, 13236-13242. doi:10.1002/chem.201001702

33. Thottumkara, A. P.; Bowsher, M. S.; Vinod, T. K. Org. Lett. 2005, 7, 2933-2936. doi:10.1021/ol050875o

34. Weng, Y.; Lan, T.; Sun, C.; Yang, T.; Su, W.; Xie, Y. Org. Chem. Front. 2018, 5, 2103-2107. doi:10.1039/C8Q000420J

35. Cheng, R.; Guo, T.; Zhang-Negrerie, D.; Du, Y.; Zhao, K. Synthesis 2013, 45, 2998-3006. doi:10.1055/s-0033-1338521

36. Hati, S.; Sen, S. Synthesis 2016, 48, 1389-1398. doi:10.1055/s-0035-1560416

37. Frigerio, M.; Santagostino, M.; Sputore, S. J. Org. Chem. 1999, 64, 4537-4538. doi:10.1021/jo9824596

\section{License and Terms}

This is an Open Access article under the terms of the Creative Commons Attribution License

(http://creativecommons.org/licenses/by/4.0). Please note that the reuse, redistribution and reproduction in particular requires that the authors and source are credited.

The license is subject to the Beilstein Journal of Organic Chemistry terms and conditions:

(https://www.beilstein-journals.org/bjoc)

The definitive version of this article is the electronic one which can be found at:

doi:10.3762/bjoc. 14.216 